\title{
A century of ecosystem change: human and seabird impacts on plant species extirpation and invasion on islands.
}

Thomas K Lameris, Joseph R Bennett, Louise K Blight, Marissa Giesen, Michael H Janssen, Joop JHJ Schaminée, Peter Arcese We used 116-years of floral and faunal records from Mandarte Island, British Columbia, Canada, to estimate the indirect effects of humans on plant communities via their effects on the population size of a surface-nesting, colonial seabird, the Glaucous-winged gull (Larus glaucescens). Comparing current to historical records revealed 18 extirpations of native plant species (32\% of species historically present), 31 exotic species introductions, and one case of exotic introduction followed by extirpation. Contemporary surveys indicated that native species cover declined dramatically from 1986 to 2006, coincident with the extirpation of 'old-growth' conifers. Because vegetation change co-occurred with an increasing gull population locally and regionally, we tested several predictions from the hypothesis that the presence and activities of seabirds help to explain those changes. Specifically, we predicted that on Mandarte and nearby islands with gull colonies, we should observe higher nutrient loading and exotic plant species richness and cover than on nearby islands without gull colonies, as a consequence of competitive dominance in species adapted to high soil nitrogen and trampling. As predicted, we found that native plant species cover and richness were lower, and exotic species cover and richness higher, on islands with versus without gull colonies. In addition, we found that soil carbon and nitrogen on islands with nesting gulls were positively related to soil depth and exotic species richness and cover across plots and islands. Our results support earlier suggestions that nesting seabirds can drive rapid change in insular plant communities by increasing nutrients and disturbing vegetation, and that human activities that affect seabird abundance may therefore indirectly affect plant community composition on islands with seabird colonies. 
1 A century of ecosystem change: human and seabird impacts on plant species extirpation and 2 invasion on islands

3

4 Thomas K. Lameris ${ }^{1,2,3}$, Joseph R. Bennett ${ }^{1,4}$, Louise K. Blight ${ }^{1,5}$, Marissa Giesen ${ }^{1}$, Michael H. Janssen ${ }^{1}$, 5 Joop Schaminée ${ }^{2}$, Peter Arcese ${ }^{1}$

6

$7{ }^{1}$ Department of Forest and Conservation Sciences, University of British Columbia, Vancouver, BC,

8 Canada

$9 \quad{ }^{2}$ Nature Conservation and Plant Ecology Group, Centre for Ecosystem Studies, Environmental Sciences

10 Group, Wageningen University, Wageningen, The Netherlands

$11{ }^{3}$ Department of Animal Ecology, Netherlands Institute of Ecology (NIOO-KNAW), Wageningen, The

12 Netherlands

$13{ }^{4}$ Institute of Environmental Science and Department of Biology, Carleton University, Ottawa, ON,

14 Canada

$15{ }^{5}$ Procellaria Research \& Consulting, Victoria, BC, Canada

16

17 Corresponding author: Thomas K. Lameris

18 Droevendaalsesteeg 10, 6708 PB Wageningen, The Netherlands

19 thomaslameris@gmail.com

20

21 Suggested running head: Seabirds and island plant communities

22

23 The authors declare that they have no conflict of interest 


\section{Abstract}

25 We used 116-years of floral and faunal records from Mandarte Island, British Columbia, Canada, to 26 estimate the indirect effects of humans on plant communities via their effects on the population size of a

27 surface-nesting, colonial seabird, the Glaucous-winged gull (Larus glaucescens). Comparing current to 28 historical records revealed 18 extirpations of native plant species (32\% of species historically present), 31

29 exotic species introductions, and one case of exotic introduction followed by extirpation. Contemporary

30 surveys indicated that native species cover declined dramatically from 1986 to 2006, coincident with the

31 extirpation of 'old-growth' conifers. Because vegetation change co-occurred with an increasing gull

32 population locally and regionally, we tested several predictions from the hypothesis that the presence and

33 activities of seabirds help to explain those changes. Specifically, we predicted that on Mandarte and

34 nearby islands with gull colonies, we should observe higher nutrient loading and exotic plant species

35 richness and cover than on nearby islands without gull colonies, as a consequence of competitive 36 dominance in species adapted to high soil nitrogen and trampling. As predicted, we found that native

37 plant species cover and richness were lower, and exotic species cover and richness higher, on islands with

38 versus without gull colonies. In addition, we found that soil carbon and nitrogen on islands with nesting 39 gulls were positively related to soil depth and exotic species richness and cover across plots and islands.

40 Our results support earlier suggestions that nesting seabirds can drive rapid change in insular plant 41 communities by increasing nutrients and disturbing vegetation, and that human activities that affect 42 seabird abundance may therefore indirectly affect plant community composition on islands with seabird 43 colonies. 


\section{Introduction}

45 Species invasion and long-term change in communities are key themes in ecology (Pickett, Collins \&

46 Armesto, 1987; Strayer et al., 2006) but rarely studied over multiple decades (Bakker et al., 1996).

47 Comparing contemporary and historical surveys can help rectify this deficit and enhance understanding of

48 long-term ecological change (Macdougall \& Turkington, 2005; Arcese et al., 2014; McKechnie et al.,

49 2014). In particular, human disturbance, habitat conversion and exotic species invasion are widely

50 acknowledged drivers of plant community change (Davis, Grime \& Thompson, 2000; Macdougall \&

51 Turkington, 2005; Seabloom et al., 2006) and can act indirectly following predator removal or herbivore

52 introduction to facilitate trophic cascades, particularly on islands (Estes et al., 2011; Arcese et al., 2014).

53 Similar observations suggest that humans may also affect island plant communities indirectly by affecting

54 population size in island-nesting seabirds, such as by introducing predators, harvesting, providing

55 anthropogenic foods or depleting their prey (Croll et al., 2005; Mulder et al., 2011; Baumberger et al.,

56 2012). Physical disturbance and chemical inputs to vegetation have often been linked to changes in nest

57 density or guano deposition by gulls (Laridae; Sobey and Kenworthy 1979, Ellis 2005) and cormorants

58 (Phalacrocoracidae; Ishida 1996, 1997). On islands with historically low seabird abundances, increased

59 guano deposition may cause long-lasting changes in soil chemistry and nutrients (García et al., 2002;

60 Wait, Aubrey \& Anderson, 2005; Caut et al., 2012) that facilitate increases in the cover and richness of

61 species adapted to nutrient-rich soils (Baumberger et al., 2012), but reducing cover and richness in species

62 adapted to poor, shallow soils (García et al., 2002; Ellis, 2005). We therefore expected that increasing

63 seabird populations and guano deposition on islands will favour some plant species over others and drive

64 plant community composition (Baumberger et al., 2012).

65

66 In this paper, we provide a case study to illustrate these ideas by using multiple data sources to examine

67 the effects of seabirds on plant communities on islands of the Georgia Basin, British Columbia (BC),

68 Canada. We focus on Mandarte Island, which has been surveyed sporadically for vegetation cover and

69 regularly for the abundance of nesting glaucous-winged gulls (Larus glaucescens). Gulls increased 
70 rapidly after gaining protection in the early 1900 s, when about 240 pairs nested on Mandarte, to 2500

71 breeding pairs in 1985 (Blight, Drever \& Arcese, 2015; supplementary material), consistent with the

72 finding that human activities have been the key driver of change in the abundance of colonially nesting

73 gulls in our study region over the last century (Blight et al., 2014; Blight, Drever \& Arcese, 2015;

74 Hobson, Blight \& Arcese, 2015). The number of nesting cormorants (Phalacrocorax spp.) on Mandarte

75 Island also increased to the mid-1980s following their protection (Drent et al. 1964, Chatwin, Mather \&

76 Giesbrecht, 2002).

78 We asked whether these impacts of humans on regional seabird populations may also have contributed

79 indirectly to long-term change in plant communities on Mandarte Island. To do so, we used opportunistic

80 and systematic data sets collected over 116 years (non-continuously), including historical photographs,

81 expedition notes, published accounts, and historical and contemporary surveys of plant species cover,

82 richness and soil nutrients to ask: 1) how native and exotic plant species richness and cover changed on

83 Mandarte Island from 1896 to 2012; and 2) what contemporary relationships exist between gull presence

84 and plant community composition on islands in our study region with and without gull breeding colonies.

85 Our results support the suggestion that humans affect plant communities indirectly via their effects on

86 seabird abundance (Croll et al. 2005) and imply that population increases in gulls over the last century

87 have facilitated rapid change in plant communities on islands with nesting seabirds.

89 Materials \& Methods

90 Study site

91 Contemporary surveys of plant communities occurred on Mandarte (48.38 N, 123.17 W; 6.8 ha) and 24

92 nearby islands ( 0.3 - 11.5 ha, within a $100 \mathrm{~km}$ radius of Mandarte). All islands are uninhabited,

93 experience a sub-Mediterranean climate regime of mild, wet winters and warm, dry summers

94 (MacDougall et al., 2006), and support maritime meadow and Garry oak (Quercus garryana) ecosystem

95 flora. This ecosystem has declined 95\% in extent in Canada since 1860 and is now severely threatened in 
96 the Georgia Basin region (Gedalof, Pellat \& Smith, 2006; Lea, 2006; Bennett \& Arcese, 2013). Mandarte

97 Island supports a mix of mature shrubs on deeper soils and herbaceous meadows in shallower soils, and

98 was managed for aboriginal plant food harvest prior to European colonization of the region (e.g., Lea

99 2006, Arcese et al. 2014). Mandarte Island also hosts the largest seabird colony in south-western BC,

100 with, over time, an estimated 200-1650 breeding pairs of pelagic ( $P$. pelagicus $)$ and double-crested

101 cormorants (P. auritus), 100-150 pairs of pigeon guillemots (Cepphus columba) and 5-125 pairs of

102 rhinoceros auklets (Cerorhinca monocerata), all nesting on cliff ledges (cormorants) or in burrows

103 (Chatwin et al. 2002, P. Arcese unpubl. data). Glaucous-winged gulls (Larus glaucescens) nest mainly in

104 the island's open or shrubby meadows and have varied in number from c 240 to 2500 breeding pairs, with

105 a peak count in 1985 (Drent \& Guiguet, 1961; Drent et al., 1964; Campbell et al., 1990; Blight, 2012;

106 Blight, Drever \& Arcese, 2015), but also on other islands throughout the Georgia Basin (Vermeer \&

107 Butler, 1989). Mandarte is similar in size and isolation to many islands that we surveyed without seabird

108 colonies, all of which are likely to have been visited regularly by humans in the last century. From the

1091860 s to 1900 s, most islands were probably visited by colonist-explorers and First Nations and colonist

110 foragers. Pleasure boaters visited and camped on most of the islands we surveyed until 2003, when many

111 were protected from human access. Although we cannot estimate human visitation rate to the islands we

112 surveyed, we would not expect that differences in human visitation could account for the vegetation

113 communities we surveyed on Mandarte and other islands in the vicinity.

115 Historical records from Mandarte Island

116 Partial accounts of Mandarte Island flora and fauna appear as museum records as early as 1896, including

117 notes on seabird presence and abundance, plant species occurrence, and photographs, all depicting a

118 vegetation community historically characteristic of a maritime Garry oak ecosystem (e.g., Tompa 1963,

119 Drent et al. 1964). Various researchers subsequently conducted periodic surveys after 1955, mainly

120 recording plants as species lists and seabirds as counts, but also documenting early changes in the plant

121 community and linking those changes to contemporary increases in gull and cormorant numbers (Drent et 
122 al. 1964). We compiled historical records of plant species occurrence from the archived museum reports,

123 herbarium specimens and lists provided by Tompa (1963) and Drent et al. (1964), and then compared

124 these lists to contemporary surveys conducted by P.A., M.G. and T.K.L. Here, we list all plant species

125 recorded on Mandarte Island to 2012 and classified each as extirpated or extant, and as native or exotic to

126 the Pacific coast of North America (Table S1). Historical photos of the island also allow qualitative

127 comparisons to a 1964 photo by P. Grant covering a sizeable portion of Mandarte Island and including all

128 typical habitats, which we replicated in 2002 (Fig. 1).

130 Vegetation surveys

131 To estimate temporal change in shrub species richness and cover on Mandarte Island, we surveyed

132 vegetation cover from June-July, 1986 and 2006, in 132, 20 x 20 m grid-squares mapped onto a 1974 air

133 photo. Surveys comprised c $90 \%$ of island area, but excluded some areas at the edge of sparsely- or non-

134 vegetated bluffs. In each square we estimated the percent cover of all perennial shrubs and common

135 herbaceous plants by species, exposed rock, and all graminoids as a group. Soil depth was estimated by

136 hammering a graduated rod into the soil at five equidistant locations at the square and $1 \mathrm{~m}$ in from each

137 corner of the square.

138

139 In June 2012, we also conducted contemporary surveys on islands adjacent to Mandarte Island to compare

140 native species richness and cover, exotic species richness and cover, and total $\mathrm{N}$ and $\mathrm{C}$ in soil on islands

141 with and without nesting glaucous-winged gulls, including three islands with gull colonies ('gull

142 islands'), namely Mandarte, Arbutus (48.71 N, -123.44 W, 35-150 nesting pairs, 1976 - 2010) and the

143 unnamed islet south of Mandarte (48.63 N, -123.28 W, 0-106 nesting pairs, 1962 - 2010; Drent et al.

144 1964, Blight 2012). Cover of herbaceous and grass species and bare soil were estimated following

145 Bennett et al. (2012; $\mathrm{N}=14 \times 1 \mathrm{~m}^{2}$ quadrats on Mandarte Island; $\mathrm{N}=4$ on Arbutus Island; $\mathrm{N}=3$ on

146 unnamed islet). Quadrat locations were selected randomly within grid cells, for a random set of all

147 mapped grid-squares that included meadow habitat. Plot-level data on soil depth was collated as the mean 
148 of four depths at quadrat corners. Total soil nitrogen, carbon and moisture were estimated by collecting

$149100 \mathrm{~g}$ of soil from five sub-samples ca. $2 \mathrm{~cm}$ below the rooting zone, then sieved $(2 \mathrm{~mm})$ and ground $(\leq$

$150 \quad 0.14 \mathrm{~mm}$ ) for analysis (Fisons NA-1500 combustion elemental analyser). Soil moisture was estimated

151 from oven-dried $\left(105^{\circ} \mathrm{C}\right)$ sub-samples. Data from 21 quadrats collected on the three gull islands were

152 compared to 57 quadrats from 22 islands in the same region not known to have supported persisting gull

153 populations ('non-gull islands'; Table S2).

154

155 For permission to access study sites, we obtained permits from Parks Canada and the Gulf Islands

156 National Park Reserve (permit number \#GINP-2008-1433), the US Fish and Wildlife Service (permit

157 number \#07002) and were given oral permission by Tswaout and Tseycum bands and by A.J. Brumbaum

158 and P. Green.

159

160 Statistical analyses

161 Vegetation survey data from Mandarte Island collected in paired plots in 1986 and 2006 were compared

162 using Wilcoxon matched-pairs tests. Comparisons of quadrat data on gull and non-gull islands used

163 Wilcoxon signed-rank tests to test for differences in native and exotic species richness and cover and total

164 soil $\mathrm{N}$ and $\mathrm{C}$. To test for links between native and exotic species richness, cover, and soil conditions on

165 gull versus non-gull islands we used generalized linear mixed models. Specifically, we constructed

166 models to explain cover and richness, native cover and richness, and the proportion of exotic vs. native

167 cover and richness using soil depth, total soil $\mathrm{N}$ and $\mathrm{C}$, and presence of seabirds as fixed effects. We

168 included island identity as a random factor in these models to account for repeat sampling within islands.

169 Percentage cover was transformed using arcsine square root (for proportion) and richness was

170 transformed using $\log +1$ to normalize residual errors. We selected models based on AIC and estimated $p$ -

171 values for predictors using Markov-chain Monte Carlo sampling (Baayen, Davidson \& Bates, 2008).

172 Total $\mathrm{N}$ and $\mathrm{C}$ were highly correlated; however, because exploratory models indicated that each variable

173 explained an independent fraction of variation in plant survey data, both variables were retained in our 
174 analyses, but interpreted cautiously. All mixed models used the lme4 package (Bates, Maechler \& Bolker,

175 2012) in R v.2.15.1 (R Development Core Team, 2014).

176

177 Results

178 Historical Comparisons

179 Over 116 years we detected 18 extirpations of native species from Mandarte Island, representing a loss of

$18032 \%$ of all native plant species recorded there. In contrast, we detected 31 colonization events by exotic

181 species, two apparent colonisations of native species, and four extirpations of exotic species known to

182 have become established prior to 1960 (Table S1). Forty-five native and one exotic species identified on

183 Mandarte Island prior to 1960 remained extant on the island as of 2012 , but $94 \%$ of exotic colonization

184 events occurred after 1960. Visual comparison of historic and contemporary photos (Fig. 1) and our

185 observations over 35 years (PA) also suggest long-term declines in shrub cover and extent of bare rock.

186 Photos document the extirpation of three tree species: grand fir (Abies grandis), arbutus (Arbutus

187 menziesii) and Douglas-fir (Pseudotsuga menziesii). Comparing the diameter of dead Douglas-fir on

188 Mandarte (c $60-180 \mathrm{~cm} \mathrm{DBH}$ ) to felled trees of similar size on adjacent islands suggests the largest

189 individuals on Mandarte Island recruited about 300 yrs BP (unpubl. observations).

190

191 Contemporary Surveys

192 Comparisons of contemporary surveys in 1986 and 2006 indicate a 31\% decline in shrub cover on

193 Mandarte Island $(\mathrm{N}=132, \mathrm{p}=0.002)$. On average, snowberry (Symphoricarpos albus) declined from

$19433 \%$ to $19 \%$ cover $(\mathrm{p}<0.001)$, Nootka rose (Rosa nutkana) from $24 \%$ to $20 \%(\mathrm{p}=0.04)$, and gooseberry

195 (Ribes divericatum), from 3\% to $0.8 \%(\mathrm{p}<0.001)$, whereas the exotic Himalayan blackberry (Rubus

196 armeniacus) and native red elderberry (Sambucus racemosa) increased from 2 to $18 \%$ and 1 to $6 \%$,

197 respectively $(\mathrm{p}<0.001)$. The extent of bare rock declined from 38 to $34 \%(\mathrm{p}=0.03)$ as grass cover

198 increased (31 to $40 \% ; \mathrm{p}<0.001)$.

199 
Influence of Gull Colonies

201 Surveys of island meadow-plants indicate that exotic species cover was significantly higher on islands

202 with $(63 \%, \mathrm{~N}=21)$ versus without gull colonies $(12 \%, \mathrm{~N}=57$; Fig. 2). In contrast, native species cover

203 and richness were lower on islands with versus without gull colonies (cover: $28.7 \pm 6.1 \%$ with vs. $45.9 \pm$

$2043.2 \%$ without; $p=0.01$; richness: $1.67 \pm 0.30$ species with versus $7.30 \pm 0.49$ species without; $p<0.001$;

205 Fig. 2).

206

207 Quadrats on gull islands also yielded higher total nitrogen $(\mathrm{N})$ and total carbon (C) concentrations than on 208 non-gull islands (nitrogen: $2.86 \pm 0.17 \%$ with vs. $1.66 \pm 0.10 \%$ without; $\mathrm{p}<0.001$; carbon: $30.31 \pm$

$2092.03 \%$ with vs. $23.19 \pm 1.44 \%$ without; $\mathrm{p}=0.01$ ). Total $\mathrm{C}$ and $\mathrm{N}$ were also positively related to soil depth

$210(r=0.58, \mathrm{p}=0.006$ and $r=0.51, \mathrm{p}=0.02$; respectively $)$, but only on gull-islands. In contrast, mean soil

211 depth was similar on gull and non-gull islands $(11.14 \pm 1.33$ with vs $19.37 \pm 2.51 \mathrm{~cm})$.

212

213 The presence of gull colonies was the only fixed effect retained in generalized mixed models to predict

214 exotic cover (positive effect), the proportion of exotic versus native cover (positive effect), and native

215 richness (negative effect; Table 1). In contrast, total C was the only fixed effect retained in models

216 predicting exotic richness (negative effect) and native cover (positive effect). Both total C and total $\mathrm{N}$

217 were retained in the top model to predict proportion exotic and native species richness, whereas soil depth

218 was not retained in any top model (Table 1).

219

\section{Discussion}

221 A comparison of historical and modern vegetation surveys confirms that substantial change in plant

222 species cover, richness and origin occurred from 1896 - 2012 on Mandarte Island. Observations from

223 historic photographs, plant lists and anecdotal reports are also consistent with the idea that these changes

224 were driven in part by increases in the abundance of nesting seabirds on the island after 1920.

225 Contemporary surveys of 24 islands with and without nesting seabirds further suggested that nesting 
226 seabirds increase soil $\mathrm{C}, \mathrm{N}$ and depth, which can facilitate non-native grasses and inhibit recruitment and

227 survival in native plant species adapted to poor, shallow soils (e.g., Bennett et al. 2012, Best \& Arcese

228 2009). Gulls and other surface-nesting seabirds such as cormorants are also reported as agents of change

229 in soil and plant communities elsewhere (Ellis, 2005; Mulder et al., 2011). Thus, despite limits on the

230 quality and scope of our data, our results are consistent with the idea that long-term vegetation change on

231 Mandarte Island has been caused in part via the effects of humans on seabird abundance.

232

233 Direct impacts of seabirds on vegetation include the input and distribution of guano, which can be toxic or 234 inhibit photosynthesis (Ishida, 1997), and physical disturbance due to trampling, nest construction and 235 territory defence (Sobey \& Kenworthy, 1979; Ellis, 2005). As reported elsewhere, we also found that 236 islands with gull colonies had higher soil $\mathrm{C}$ and $\mathrm{N}$ concentrations than those without them (e.g., Anderson 237 \& Polis, 1999; Wait, Aubrey \& Anderson, 2005). Ellis (2005) suggested that surface-nesting seabirds 238 enhanced soil depth in systems without mammalian herbivores by facilitating litter accumulation; this 239 observation is consistent with an observed decline in exposed rock on Mandarte Island, and with positive 240 correlations between soil depth and $\mathrm{C}$ and $\mathrm{N}$ concentrations on islands with (but not without) gull 241 colonies. In addition to the effects of seabirds, however, we also acknowledge that many other changes

242 have occurred in our study system over the last century, including changes in the use of fire to maintain 243 communities aboriginal peoples of the region (MacDougal et al 2005, Arcese et al. 2014), as well as 244 increased visitation by European colonists and others. While it is possible that the cessation of burning 245 might increase soil depth over time, burning also ceased on a number of the islands without nesting 246 seabirds, which still support most or all of the plant species extirpated from Mandarte Island (Bennet \&

247 Arcese 2013). We are also unaware of any systematic differences between the islands we surveyed with 248 and without gulls linked to their size, isolation or human visitation rates that could account for the 249 floristic differences we report.

251 Plant Species Cover and Richness 
252 A key result of our work was the observation that $32 \%$ of 63 native plant species historically extant on

253 Mandarte Island were extirpated by 2012. In contrast, we documented 31 colonizations of Mandarte

254 Island by exotic plant species. Although we lack precise dates for introductions, many appear to have

255 been facilitated by exotic birds, such European starling Sturnus vulgaris, which began using Mandarte

256 Island as a night roost in the 1970s and are well-documented as seed dispersers (Arcese, 1989; Mcatee,

257 2009; Bennett et al., 2011). However, given that many exotic plant species that we detected are widely

258 distributed in the Georgia Basin and good dispersers (Bennett, 2014), it is also possible that some

259 invasions we detected were facilitated by human visitors. Exotic grasses abundant on Mandarte Island,

260 such as Bromus rigidus (19.6\% cover) and Dactylis glomerata (14.5\% cover), also occur in many Garry

261 oak and maritime meadows, but are only common in those disturbed by humans or livestock (e.g.,

262 Gonzales and Arcese 2008, Bennett et al. 2012), especially in nutrient-rich soils (Klinkenberg, 2012).

263 These points suggest that the invasion, establishment and dominance of at least some exotic invaders to

264 Mandarte Island was facilitated by interactions between birds, humans and changing soils.

265

266 Three tree species established on Mandarte Island prior to 1896 remained extant into the 1960s (arbutus),

267 1980s (grand fir) and 1990s (Douglas-fir), but were extirpated by 2002, including individual Douglas-firs

268 likely to have been $\geq 300$ years-old (Fig. 1). Although declines in conifer survival have been linked to

269 decreased precipitation in our study region (Murdock et al., 2012), guano and physical damage from

270 perching cormorants is well-known to kill trees in other systems (Hebert et al., 2005; Boutin et al., 2011)

271 and was reported to be underway on Mandarte Island about 1960 (Drent et al., 1964). Declines in shrub

272 cover on Mandarte Island may also be due in part to guano deposition, although the trampling and

273 shredding of shrubs and adventitious shoots by gulls was widely evident after 1981 (P.A., unpubl.

274 observations). The accumulation of soil $\mathrm{N}$ and $\mathrm{C}$ and promotion of grass cover at the expense of shrub

275 recruitment is also documented from seabird colonies elsewhere (Ishida, 1996, 1997; Ellis, 2005). The

276 colonization and spread of exotic blackberry and native red elderberry may also contribute to reduced

277 native shrub cover, as these species are adapted to shallow soils and summer drought, whereas the 
278 aforementioned species favor the moist, nutrient-rich soils which have developed more recently on

279 Mandarte Island (e.g., Bennett et al. 2012). Overall, these observations are also consistent with the idea

280 that increases in seabird abundance have contributed directly or indirectly to declines in native shrub

281 cover on Mandarte Island via a combination of mechanisms described above.

282

283 Plant Communities and Gull Colonies

284 Our observation that exotic species cover was higher on islands with than without gull colonies is

285 consistent with our finding of enriched total $\mathrm{C}$ and $\mathrm{N}$ on islands with gulls, and with earlier suggestions

286 that increases in exotic species cover co-occurred with increases in gull and cormorant abundance on

287 islands (Hogg \& Morton, 1983; Ellis, 2005; Baumberger et al., 2012). In addition, Best and Arcese (2009)

288 showed experimentally that trampling by exotic Canada geese (Branta canadensis) reduced native species

289 richness and increased exotic species dominance in maritime meadows in the Georgia Basin, confirming

290 that other species can also influence plant community change in this system, particularly on small islets

291 (Best \& Arcese, 2009; Isaac-Renton et al., 2010; Bennett \& Arcese, 2013).

292

293 The effects of seabirds on island plant communities in our study region are less certain into the future, 294 given that gulls and cormorants have declined from peak abundances estimated in the mid-1980s. In 295 gulls, reductions in diet quality linked to human overfishing and the substitution of anthropogenic for 296 marine foods, perhaps aided by the recovery of bald eagle numbers, may all have acted to reduce their 297 abundance, including on Mandarte Island (Blight, Drever \& Arcese, 2015). Declines in cormorant 298 populations have also occurred but remain unexplained (Chatwin, Mather \& Giesbrecht, 2002). It 299 remains to be seen whether these changes will result in the recovery of native dominance if disturbance is 300 sufficiently reduced and nutrient profiles attain the levels indicated on islands without nesting seabirds.

301 Nevertheless, our results offer a baseline for comparisons in future, particularly of islands in the region 302 with and without nesting seabirds present. 


\section{Acknowledgements}

305 We thank N Turner for extensive discussion, P Grant for photographs, W Cornwell, the Arcese lab and

306 NCP chair group for feedback, R Germain, P Nietlisbach, C Bousquet and S Losdat for field support and

307 C Dawson (BC Ministry of Environment) for soil analyses. Field research complied with Canadian law.

308 Comments by anonymous reviewers improved previous versions of the manuscript.

309

310 References

311 Anderson WB., Polis GA. 1999. Nutrient fluxes from water to land : seabirds affect plant nutrient status 312 on Gulf of California islands. Oecologia 118:324-332.

313 Arcese P. 1989. Intrasexual competition, mating system and natal dispersal in song sparrows. Animal 314 Behaviour 38:958-979.

315 Arcese P., Schuster R., Campbell L., Barber A., Martin TG. 2014. Deer density and plant palatability

316 predict shrub cover, richness and aboriginal food value in a North American island archipelago.

317 Diversity and Distributions 20:1368-1378.

318 Baayen RH., Davidson DJ., Bates DM. 2008. Mixed-effects modeling with crossed random effects for 319 subjects and items. Journal of Memory and Language 59:390-412.

320 Bakker JP., Olff H., Willems JH., Zobel M. 1996. Why do we need permanent plots in the study of long321 term vegetation dynamics? Journal of Vegetation Science 7:147-155.

322 Bates D., Maechler M., Bolker B. 2012. lme4: Linear mixed-effects models using S4 classes.

323 Baumberger T., Affre L., Torre F., Vidal E., Dumas P-J., Tatoni T. 2012. Plant community changes as 324 ecological indicator of seabird colonies' impacts on Mediterranean Islands. Ecological Indicators $325 \quad 15: 76-84$.

326 Bennett JR., Young EJ., Giblin DE., Dunwiddie PW., Arcese P. 2011. Avian Dispersal of Exotic Shrubs 327 in an Archipelago. Ecoscience 18:369-374.

328 Bennett JR., Dunwiddie PW., Giblin DE., Arcese P. 2012. Native versus exotic community patterns 329 across three scales : Roles of competition, environment and incomplete invasion. Perspectives in 
331 Bennett JR. 2014. Comparison of native and exotic distribution and richness models across scales reveals 332 essential conservation lessons. Ecography 37:120-129.

333 Bennett JR., Arcese P. 2013. Human Influence and Classical Biogeographic Predictors of Rare Species

334 Occurrence. Conservation Biology 27:417-421.

335 Best RJ., Arcese P. 2009. Exotic herbivores directly facilitate the exotic grasses they graze: mechanisms

336 for an unexpected positive feedback between invaders. Oecologia 159:139-50.

337 Blight LK. 2012. Glaucous-winged Gulls Larus glaucescens as sentinels for a century of ecosystem

338 change - long term trends in population, diet, and egg production in North America's Salish Sea.

$339 \quad \mathrm{PhD}$ dissertation, University of British Columbia.

340 Blight LK., Hobson K a., Kyser TK., Arcese P. 2014. Changing gull diet in a changing world: A 150-year

341 stable isotope $(\delta 13 \mathrm{C}, \delta 15 \mathrm{~N})$ record from feathers collected in the Pacific Northwest of North

342 America. Global Change Biology 21:1497-1507.

343 Blight LK., Drever MC., Arcese P. 2015. A century of change in Glaucous-winged Gull ( Larus

344 glaucescens ) populations in a dynamic coastal environment. The Condor 117:108-120.

345 Boutin C., Dobbie T., Carpenter D., Hebert CE. 2011. Effects of Double-Crested Cormorants

346 (Phalacrocorax auritus Less.) on Island Vegetation, Seedbank, and Soil Chemistry: Evaluating

347 Island Restoration Potential. Restoration Ecology 19:720-727.

348 Campbell W., Dawe NK., McTaggart-Cowan I., Cooper JM., Kaiser GW., McNall MC. 1990. Birds of

349 British Columbia, Volume 2: Nonpasserines-Diurnal Birds of Prey through Woodpeckers.

$350 \quad$ Vancouver: UBC press.

351 Caut S., Angulo E., Pisanu B., Ruffino L., Faulquier L., Lorvelec O., Chapuis JL., Pascal M., Vidal E.,

352 Courchamp F. 2012. Seabird modulations of isotopic nitrogen on islands. PLoS ONE 7:1-7.

353 Chatwin TA., Mather MH., Giesbrecht TD. 2002. Changes in Pelagic and Double-Crested Cormorant

354 Nesting Populations in the Strait of Georgia, British Columbia. Northwestern Naturalist 83:109-

$355 \quad 117$. 
356 Croll DA., Maron JL., Estes JA., Danner EM., Byrd G V. 2005. Introduced predators transform subarctic 357 islands from grassland to tundra. Science 307:1959-1961.

358 Davis MA., Grime JP., Thompson K. 2000. in plant communities : Fluctuating resources a general of 359 invasibility theory. 88:528-534.

360 Drent R., van Tets GF., Tompa FS., Vermeer K. 1964. The breeding birds of Mandarte Island, British 361 Columbia. The Canadian field-naturalist 78:208-263.

362 Drent RH., Guiguet C. 1961. A Catalogue of British Columbia Seabird Colonies. Victoria, BC.

363 Ellis JC. 2005. Marine Birds on Land: A Review of Plant Biomass, Species Richness, and Community 364 Composition in Seabird Colonies. Plant Ecology 181:227-241.

365 Estes JA., Terborgh J., Brashares JS., Power ME., Berger J., Bond WJ., Carpenter SR., Essington TE., 366 Holt RD., Jackson JBC., Marquis RJ., Oksanen L., Oksanen T., Paine RT., Pikitch EK., Ripple WJ., 367 Sandin SA., Scheffer M., Schoener TW., Shurin JB., Sinclair ARE., Soulé ME., Virtanen R., Wardle 368 DA. 2011. Trophic downgrading of planet Earth. Science 333:301-6.

369 García LV., Marañón T., Ojeda F., Clemente L., Redondo R., Garcia L V., Marainon T., Redondo R.

370 2002. Seagull influence on soil properties, chenopod shrub distribution, and leaf nutrient status in 371 semi-arid Mediterranean islands. Oikos 98:75-86.

372 Gedalof Z., Pellat M., Smith DJ. 2006. From Prairie to Forest: Three Centuries of Environmental Change 373 at Rocky Point, Vancouver Island, British Columbia. Northwest Science 80:34-46.

374 Gonzales EK., Arcese P. 2008. Herbivory more limiting than competition on early and established native 375 plants in an invaded meadow. Ecology 89:3282-3289.

376 Hebert CE., Duffe J., Weseloh DVC., Senese TED., Haffner GD. 2005. Unique island habitats may be 377 threatened by Double-crested Cormorants. Journal of Wildlife Management 69:68-76.

378 Hobson KA., Blight LK., Arcese P. 2015. Human-Induced Long-Term Shifts in Gull Diet from Marine to 379 Terrestrial Sources in North America's Coastal Pacific: More Evidence from More Isotopes $\left(\delta^{2} \mathrm{H}\right.$, $380 \quad \delta^{34}$ S). Environmental Science \& Technology:150826155926009.

381 Hogg EH., Morton JK. 1983. The effects of nesting gulls on the vegetation and soil of islands in the Great 
Lakes. Canadian Journal of Botany 61:3240-3254.

383 Isaac-Renton M., Bennett JR., Best RJ., Arcese P. 2010. ) on Native Plant Communities of the Southern

384 Gulf Islands, British Columbia. Ecoscience 17:394-399.

385 Ishida A. 1996. Effects of the common cormorant, Phalacrocorax carbo, on evergreen forests in two nest 386 sites at Lake Biwa, Japan. Ecological Research 11:193-200.

387 Ishida A. 1997. Seed germination and seedling survival in a colony of the common cormorant,

388 Phalacrocorax carbo. Ecological Research 12:249-256.

389 Klinkenberg B. 2012. E-Flora BC: Electronic Atlas of the Flora of British Columbia [eflora.bc.ca].

390 Lea T. 2006. Historical Garry Oak Ecosystems of Vancouver Island, British Columbia, pre-European

391 Contact to the Present. Davidsonia 17:34-50.

392 MacDougall AS., Boucher J., Turkington R., Bradfield GE. 2006. Patterns of plant invasion along an 393 environmental stress gradient. Journal of Vegetation Science 17:47.

394 Macdougall AS., Turkington R. 2005. Are invasive species the drivers or passengers of change in 395 degraded ecosystems? Ecology 86:42-55.

396 Mcatee AWL. 2009. Distribution of Seeds by Birds. American Midland Naturalist 38:214-223.

397 McKechnie I., Lepofsky D., Moss ML., Butler VL., Orchard TJ., Coupland G., Foster F., Caldwell M.,

398 Lertzman K. 2014. Archaeological Data Provide Alternative Hypotheses on Pacific Herring (Clupea 399 pallasii) Distribution, Abundance, and Variability. Proceedings of the National Academy of Sciences $400 \quad$ of the United States of America 111:E807-E816.

401 Mulder CPH., Anderson WB., Towns DR., Bellingham PJ. 2011. Seabird islands: ecology, invasion, and 402 restoration. Oxford: Oxford University Press.

403 Murdock TQ., Sobie SR., Eckstrand HD., Jackson E. 2012. Georgia Basin: Projected Climate Change,

404 Extremes, and Historical Analysis. Pacific Climate Impacts Consortium.

405 Pickett STA., Collins SL., Armesto JJ. 1987. A hierarchical consideration of causes and mechanisms of $406 \quad$ succession. Vegetatio 69:109-114.

407 R Development Core Team. 2014. R: A language and environment for statistical computing. 
408 Seabloom EW., Williams JW., Slayback D., Stoms DM., Viers JH., Dobson AP. 2006. Human impacts, 409 plant invasion, and imperiled plant species in California. Ecological applications : a publication of $410 \quad$ the Ecological Society of America 16:1338-50.

411 Sobey ADG., Kenworthy JB. 1979. The relationship between Herring Gulls and the vegetation of their 412 breeding colonies. Journal of Ecology 67:469-496.

413 Smith JNM., Keller LF., Marr AB., Arcese P. 2006. Conservation and Biology of Small Populations: The 414 Song Sparrows of Mandarte Island. Oxford: Oxford University Press

415 Strayer DL., Eviner VT., Jeschke JM., Pace ML. 2006. Understanding the long-term effects of species 416 invasions. Trends in ecology \& evolution 21:645-51.

417 Tompa FS. 1963. Factors determining the numbers of Song Sparrows on Mandarte Island, B.C.

$418 \quad$ University of British Columbia.

419 Vermeer K., Butler RW. 1989. The ecology and status of marine and shoreline birds in the Strait of 420 Georgia, British Columbia. Ottawa: Spec. Publ. Can. Wild. Serv.

421 Wait D a., Aubrey DP., Anderson WB. 2005. Seabird guano influences on desert islands: soil chemistry 422 and herbaceous species richness and productivity. Journal of Arid Environments 60:681-695. 
1

Comparison of photographs of central woodland on Mandarte Island (1964 - 2002).

(A) Historical photograph from 1964 (by Peter Grant; Smith et al. 2006) and (B) a recent reproduction made in 2002 (by Peter Arcese). Note mature Arbutus menziesii and Pseudotsuga menziesii in the historical photograph. The latter include 3 individuals 0.8 $1.4 \mathrm{~m}$ in basal diameter, and estimated at $250-400$ years-old by comparison to newly harvested trees on adjacent islands.

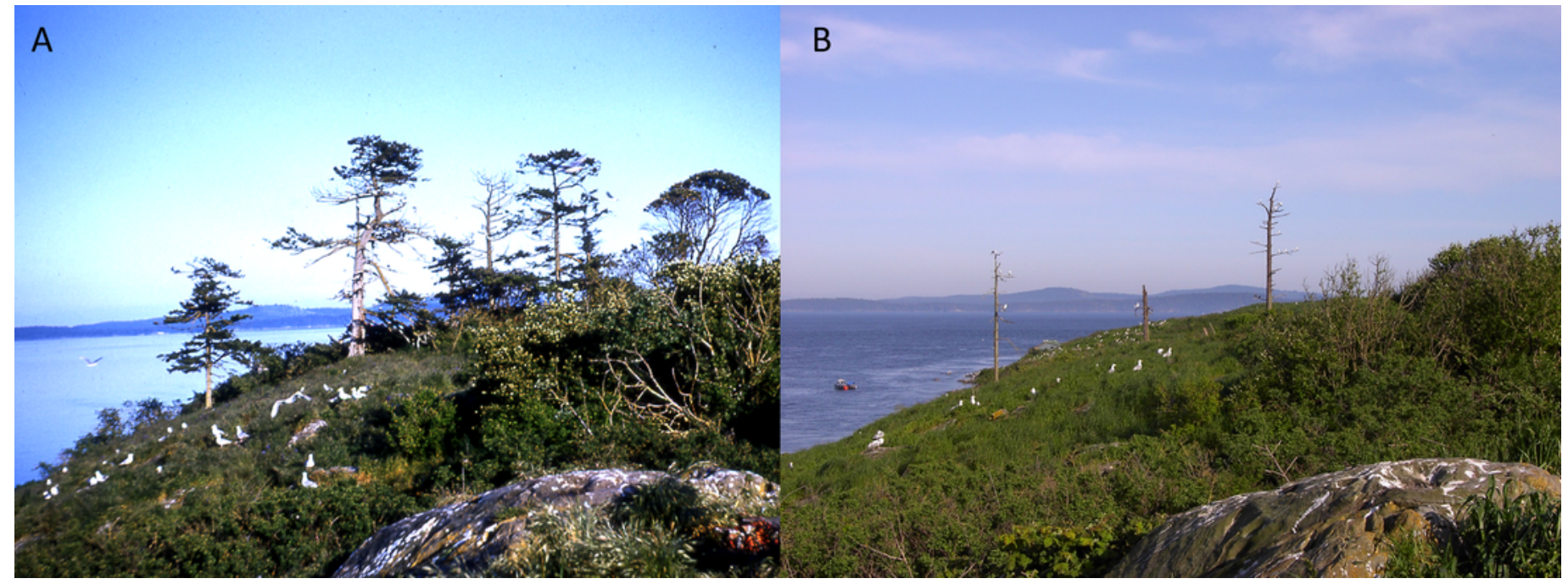


2

Native and exotic species cover and richness on islands with and without gull colonies.

Box-plots showing differences in (A) species cover and (B) species richness of exotic and native species, on islands with gull colonies (white columns) and without (grey columns). Asterisks denote significant differences in Wilcoxon tests (double: $p<0.01$; triple: $p<$ $0.001)$.
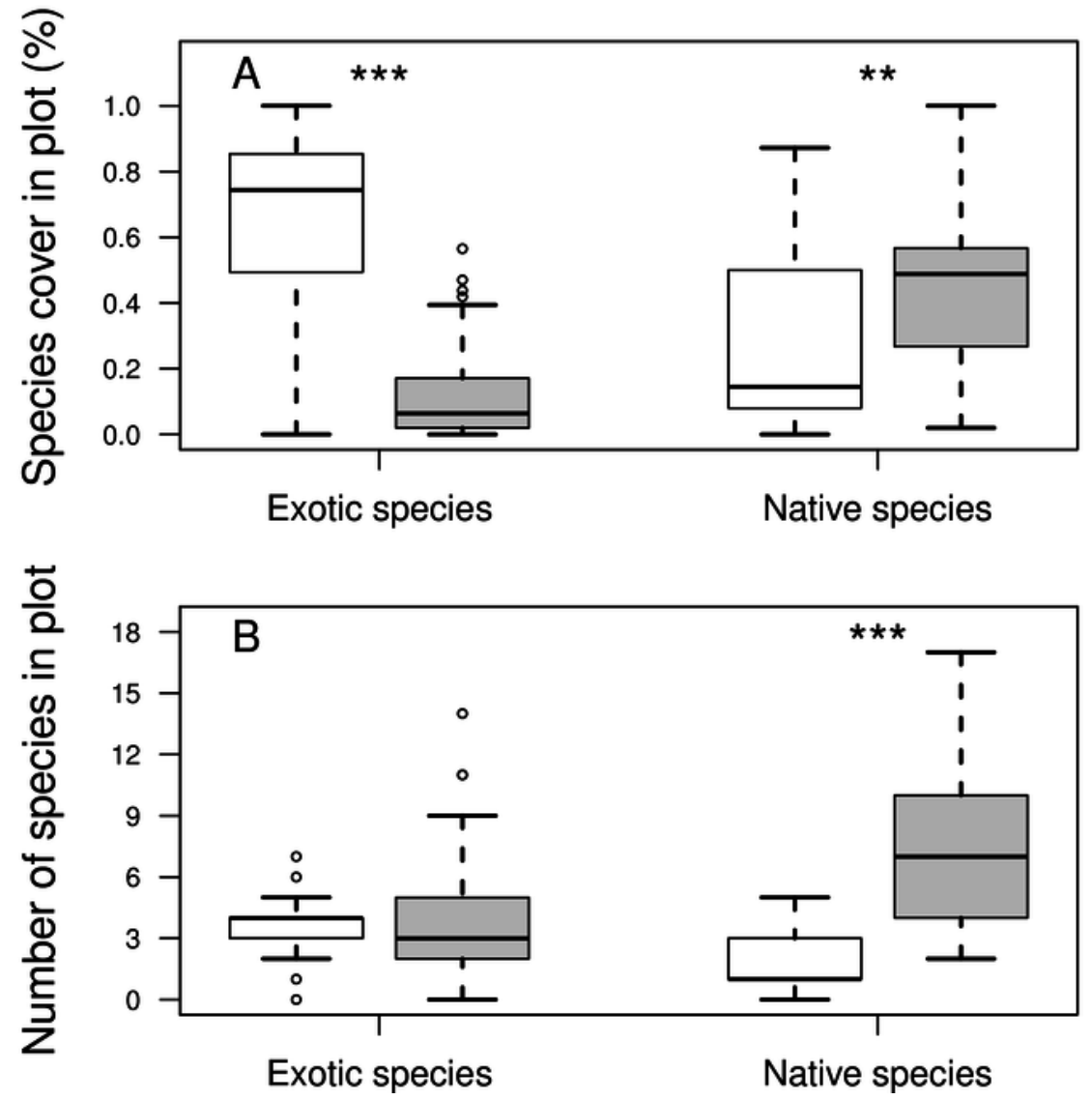


\section{Table $\mathbf{1}$ (on next page)}

Significant coefficients from several generalized mixed models relating vegetation composition and environmental variables. 


\begin{tabular}{|c|c|c|c|c|c|c|}
\hline Response variable & $\begin{array}{l}\text { Predictor } \\
\text { variables }\end{array}$ & Coefficients & $\begin{array}{l}\text { Coefficient } \\
\text { value }\end{array}$ & $\begin{array}{l}\text { Standard } \\
\text { error }\end{array}$ & $\mathbf{t}$ & $P$ \\
\hline $\begin{array}{l}\text { Proportion exotic } \\
\text { cover }^{1}\end{array}$ & $\mathrm{~N}, \mathrm{C}, \mathrm{S}, \mathrm{B}$ & B & 0.449 & 0.162 & 2.776 & 0.007 \\
\hline Exotic cover ${ }^{1}$ & $\mathrm{~N}, \mathrm{C}, \mathrm{S}, \mathrm{B}$ & $\mathrm{B}$ & 0.541 & 0.123 & 4.417 & $<0.001$ \\
\hline $\begin{array}{l}\text { Proportion exotic } \\
\text { richness }{ }^{1}\end{array}$ & $\mathrm{~N}, \mathrm{C}, \mathrm{S}, \mathrm{B}$ & $\begin{array}{l}\mathrm{C} \\
\mathrm{N}\end{array}$ & $\begin{array}{r}-0.021 \\
0.222\end{array}$ & $\begin{array}{l}0.007 \\
0.092\end{array}$ & $\begin{array}{r}-2.964 \\
2.416\end{array}$ & $\begin{array}{l}0.004 \\
0.018\end{array}$ \\
\hline Exotic richness ${ }^{2}$ & $\mathrm{~N}, \mathrm{C}, \mathrm{S}, \mathrm{B}$ & $\mathrm{C}$ & -0.008 & 0.003 & -2.762 & 0.007 \\
\hline Native cover ${ }^{1}$ & $\mathrm{~N}, \mathrm{C}, \mathrm{S}, \mathrm{B}$ & $\mathrm{C}$ & 0.008 & 0.003 & 2.225 & 0.029 \\
\hline Native richness ${ }^{2}$ & $\mathrm{~N}, \mathrm{C}, \mathrm{S}, \mathrm{B}$ & B & -0.496 & 0.056 & -8.884 & $<0.001$ \\
\hline
\end{tabular}

1

2 Response variables: ${ }^{1}$ transformed using arcsine square root. ${ }^{2}$ transformed using $\log (+1)$

3 Predictor variables: $\mathrm{N}=$ total nitrogen concentration, $\mathrm{C}=$ total carbon concentration, $\mathrm{S}=\log$ mean soil

4 depth, $\mathrm{B}=$ presence of gull colonies on island (with or without gull colonies). 